Check for updates

The BMJ

kabbasi@bmi.com

Cite this as: $B M J 2020 ; 370: m 2929$

http://dx.doi.org/10.1136/bmj.m2929

Published: 23 July 2020

\section{Covid-19: Acts of omission}

Kamran Abbasi executive editor

The UK government is becoming known for acts of omission. No evidence exists of Russian interference in the 2016 Brexit referendum because the government didn't and won't look for it. Nor does it seek lessons from an immediate public inquiry to inform a future surge of covid-19. ${ }^{1}$ Nothing predicts behaviour like behaviour, and if over 60 ooo excess deaths in six months will not force behaviour change then perhaps nothing will?

The pandemic is at its global height and anything but in retreat, exploiting a philosophical battle between prioritising health or banking on the economy. In the UK and US, the economy has won out. Wealth before health. Elsewhere, the role of health in generating wealth, and the emerging evidence behind it, is better understood. ${ }^{2}$ The European Union, for example, has announced a €75obn (£68obn; \$86obn) coronavirus recovery fund. ${ }^{3}$ Out of the EU, England is marginalising independent scientific advice. ${ }^{45}$

Acts of commission are faring little better, as the persistent struggles with testing, contact tracing, and local data flows demonstrate. ${ }^{6}{ }^{7}$ Positive talk doesn't paper over the burden on health professionals and their need to rest and recuperate, or the lack of public confidence in seeking urgent care during a pandemic. ${ }^{89} \mathrm{~A}$ genuine opportunity exists to build back better by reducing unnecessary healthcare or making better use of hospital medicines data. ${ }^{10} 11$

Clinicians can at least focus on clinical skills. Anosmia is among the myriad clinical presentations of covid-19, and one of the most talked about. Half of all patients with covid-19 lose their sense of smell, but most recover it within four weeks. ${ }^{12}$ The key challenge is staying alert for an alternative explanation. At the other end of the clinical spectrum, severely ill patients with breathlessness and agitation require palliation and clear communication about prospects with family and carers. ${ }^{13} \mathrm{As}$ the system flails, health professionals are relied on to hold it together.

Despite encouraging reports about a possible covid-19 vaccine, ${ }^{14}$ expert consensus is that the winter will bring another surge of cases. Covid-19 is no mere political power game. Further mishandling of the response will lead to more excess deaths, and premature death is a losing game for both people and the economy.

lacobucci G. Covid-19: PM promises inquiry but says it won’t happen during pandemic. BMJ2020;370:m2869. doi: 10.1136/bmi.m2869 pmid: 32675059

Ogbuoji O, Vollmer S, Jamison DT, Dickson EA, Bärnighausen T. Economic consequences of better health: insights from clinical data. BMJ2020;370:m2186. doi: 10.1136/bmi.m2186 pmid: 32690556

3 Boffey D, Rankin J. EU leaders seal deal on spending and €750bn Covid-19 recovery plans. 2020. https://www.theguardian.com/world/2020/jul/20/macronseeks-end-acrimony-eu-summit-enters-fourth-day

Torjesen I. Covid-19: Is the UK government marginalising scientists?BMJ2020;370:m2874. doi: 10.1136/bmj.m2874 pmid: 32680847

Salisbury H. Timing is everything. BMJ2020;370:m2907doi: 10.1136/bmj.m2907.

O'Dowd A. Covid-19: UK test and trace system still missing 80\% target for reaching contacts. BM/2020;370:m2875. doi: 10.1136/bmj.m2875 pmid: 32680932

Torjesen I. Covid-19: Local public health teams being denied access to data that could help them trace cases. BM/2020;370:m2883.

doi: 10.1136/bmj.m2883 pmid: 32680909

Gerada C. We must not rush back to business as usual. BM/2020;370:m2860doi: 10.1136/bmi.m2860.

9 Griffin S. Covid-19: Data show 5000 fewer hospital admissions for acute coronary syndrome during pandemic. BMJ 2020;370:m2852. doi: 10.1136/bmj.m2852 pmid: 32669278

10 Moynihan R, Johansson M, Maybee A, Lang E, Légaré F. Covid-19: an opportunity to reduce unnecessary healthcare. BMJ 2020;370:m2752. doi: 10.1136/bmj.m2752 pmid: 32665257

11 Goldacre B, MacKenna B. The NHS deserves better use of hospital medicines data. BMJ2020;370:m2607. doi: 10.1136/bmj.m2607 pmid: 32680848

12 Walker A, Pottinger B, Scott A, Hopkins C. Anosmia and loss of smell in the era of covid-19. BMJ2020;370:m2808doi: 10.1136/bmj.m2808.

13 Ting R, Edmonds P, Higginson IJ, Sleeman KE. Palliative care for patients with severe covid-19. BM/2020;370:m2710. doi: 10.1136/bmj.m2710 pmid: 32665316

14 Mahase E. Covid-19: UK agrees “early access” deal with companies to get 90 million vaccine doses. BMJ2020;370:m2914

doi: $10.1136 /$ bmj.m2914 pmid: 32690543 